\title{
Liver and Kidney Function Analysis in Hepatitis-B Patients Attending a Health Facility in Ikeja, Lagos, Nigeria
}

\section{Olu Israel OYEWOLE1 ${ }^{1}$, Mary Omolayo FAKOKUNDE1}

\author{
${ }^{1}$ Biochemistry Unit, Department of Chemical Sciences, Faculty of Basic and Applied Sciences, Osun State \\ University, Osogbo, Nigeria
}

\begin{abstract}
Objective: The study was designed to determine changes in liver and kidney function parameters associated with hepatitis B infection among patients attending Nigerian Air Force Hospital (NAFH) Ikeja, Lagos, Nigeria. Methodology: The study made use of forty subjects (aged 35-50) divided into four groups of ten each (Amale non-hepatitis, B-female non-hepatitis, C-male hepatitis, D-female hepatitis). Serum samples were collected from the hepatitis patients and analyzed for some liver and kidney function parameters in comparism with their nonhepatitis counterparts. Results: There was significant increase in activities of serum enzymes -Alkaline phosphatase (ALP), Alanine aminotransferase (ALT) and Aspartate aminotransferase (AST) in male and female hepatitis patients compared with their non-hepatitis counterpart. Serum level of total protein was significantly reduced while total bilirubin was significantly elevated in hepatitis patients compared with the control. Measurement of kidney function biomarkers in the serum of hepatitis $\mathrm{B}$ infected patients showed elevated concentrations of urea, creatinine and uric acid while serum electrolytes $\left(\mathrm{Na}^{+}, \mathrm{K}^{+}\right.$and $\left.\mathrm{Cl}^{-}\right)$were significantly reduced compared with the control. Conclusion: This results indicate that hepatitis $\mathrm{B}$ virus infection caused significant disruption of metabolic functions in the liver and kidney of the patients. This research is a further confirmation that other organ such as the kidney are negatively affected in hepatitis infection aside from the liver which is the principal target.
\end{abstract}

Keywords: Hepatitis B, liver function, kidney function, aminotransferases, electrolytes

\section{INTRODUCTION}

The prevalence of diseases associated with liver and kidney damage is on the increase across the globe with limited treatment options thereby causing major health complications and burden on the population $(1,2)$. A recent data suggests that more than $0.2 \%$ of the adult population of the world suffer either liver or kidney diseases due to increasing incidence of their risk factors including hepatitis $(3,4)$.

Hepatitis is a medical condition caused by inflammation of the liver and characterized by the presence of inflammatory cells in the tissue (5). Hepatitis virus is the most common cause of the condition globally (6). Hepatitis can also be caused by other microbial infections, alcohol, certain medications, industrial solvents and autoimmune diseases $(7,8)$. Hepatitis B virus (HBV) lives in the blood and other body fluids. HBV primarily interferes with the functions of the liver by replicating in liver cells, known as hepatocytes (9). $\mathrm{HBV}$ is transmitted from person to person through unprotected sexual intercourse with an infected person or through sharing of infected needles or other sharp instruments that break the skin (10). Babies born to an infected mother have a 90 to $95 \%$ chance of contracting HBV during childbirth (11). Although the primary organ affected by hepatitis is the liver, a number of epidemiological studies have recently shown a strong link between severity of liver disease with decreased kidney function (12).

An extensive review of scientific literature reveals that there is no sufficient data on the status of liver and kidney function in hepatitis patient in Western Nigeria. There is need to carry out biochemical analysis to investigate the extent of liver and kidney damage caused by hepatitis B infection. This research serves to measure and compare liver and kidney function parameters in hepatitis B outpatients attending NAFH Ikeja, Lagos, Nigeria with their nonhepatitis counterpart. This will serve as a case study and results obtained in this research can be applicable to other parts of Western Nigeria.

This article is published under the terms of the Creative Commons Attribution License 4.0

Author(s) retain the copyright of this article. Publication rights with Alkhaer Publications.

Published at: http://www.ijsciences.com/pub/issue/2017-04/

DOI: 10.18483/ijSci.1244; Online ISSN: 2305-3925; Print ISSN: 2410-4477 


\section{MATERIALS AND METHODS \\ Materials}

Laboratory equipment used includes high-speed centrifuge (Xiangyi ${ }^{\circledR}$ Centrifuge Instrument Co. Ltd. Model: TG16-W), automatic multiparameter blood analyzer (Selectra pro and COBAS 311), micro pipette, assay kits (ALP, ALT, AST, total protein, bilirubin, urea, creatinine, uric acid, $\mathrm{Na}^{+}, \mathrm{K}^{+}$and $\left.\mathrm{Cl}^{-}\right)$ were obtained from Quimica Clinical Applicada (QCA), Amposta, Spain.

\section{Study Population}

Patients with clinically diagnosed hepatitis B infection (tested positive for HBsAg) at the Medical Laboratory of NAFH, Ikeja, Lagos were used for the study. The study made use of forty subjects (aged 3550) divided in to four groups of ten each (A-male non-hepatitis, B-female non-hepatitis, C-male hepatitis, D-female hepatitis). Serum samples of the hepatitis B patients were analyzed and compared with non-hepatitis patients. The research was carried out with informed consent of all subjects concerned. Identity of each subject was treated with utmost secrecy to ensure confidentiality. The study was conducted following approval by the Health Research Ethical Committee of Osun State University, Osogbo.

\section{Collection of Blood and Preparation of Serum}

Blood samples were collected from the subjects into plain bottles and allowed to clot. Clotted blood was centrifuged at $4000 \mathrm{rpm}$ for 10 minutes at $4^{\circ} \mathrm{C}$ using a high-speed centrifuge (Xiangyi ${ }^{\circledR}$ Centrifuge Instrument Co., Ltd, Model: TG16-W) to obtain the serum.

\section{Biochemical Measurement}

An automatic multiparameter blood analyzer (Selectra pro and COBAS 311) was used for the serum determinations. The principle of operation of the apparatus is based on dry chemical technology and colorimetric reaction. $5 \mathrm{ml}$ of the serum was pipetted into the micro titer which was then placed in the blood analyzer and allowed to read automatically. The serum was analyzed for total protein, total bilirubin, urea, creatinine, uric acid, electrolytes $\left(\mathrm{Na}^{+}\right.$, $\mathrm{K}^{+}, \mathrm{Cl}^{-}$) and serum enzymes (ALP, ALT, AST).

\section{Statistical Analysis}

Statistical analysis was done using the SPSS program version 13.0.1 (SPSS Inc., Chicago, IL, USA). Data obtained was expressed as mean \pm SD and Values of $\mathrm{p}<0.05$ were taken as statistically significant.

\section{RESULTS}

The effects of hepatitis B virus infection on liver function parameters in infected patients compared with their non-hepatitis counterpart are shown in Table 1. There was significant elevation $(\mathrm{p}<0.05)$ in the serum levels of liver marker enzymes (ALP, ALT and AST) compared with the control. Serum concentration of total protein was significantly reduced while total bilirubin was also elevated in patients infected with hepatitis compared with nonhepatitis. Kidney function biomarkers in hepatitis B infected and non-infected patients are shown in Table 2 . There was significant elevation $(p<0.05)$ in serum concentrations of urea, creatinine and uric acid in hepatitis patients compared with the control. Serum $\mathrm{Na}^{+}, \quad \mathrm{K}^{+}$and $\mathrm{Cl}^{-}$in hepatitis subjects were significantly reduced compared with their nonhepatitis counterpart as can be seen in Table 2. There was no significant difference between male and female hepatitis as well as between male and female non-hepatitis patients in all parameters measured.

Table 1: Liver function parameters in hepatitis B infected and non-infected patients obtained at NAFH, Ikeja Lagos.

\begin{tabular}{lcccc}
\hline Group & $\begin{array}{c}\text { Male } \\
\text { Non-hepatitis }\end{array}$ & $\begin{array}{c}\text { Female } \\
\text { Non-hepatitis }\end{array}$ & Male Hepatitis & Female Hepatitis \\
\hline ALP (IU/L) & $126.80 \pm 8.87^{\mathrm{a}}$ & $131.00 \pm 7.85^{\mathrm{a}}$ & $164.00 \pm 7.62^{\mathrm{b}}$ & $170.20 \pm 9.94^{\mathrm{b}}$ \\
ALT (IU/L) & $28.60 \pm 3.17^{\mathrm{a}}$ & $27.20 \pm 2.62^{\mathrm{a}}$ & $44.60 \pm 4.31^{\mathrm{b}}$ & $41.00 \pm 5.29^{\mathrm{b}}$ \\
AST (IU/L) & $30.60 \pm 2.28^{\mathrm{a}}$ & $32.20 \pm 3.98^{\mathrm{a}}$ & $48.80 \pm 4.59^{\mathrm{b}}$ & $47.60 \pm 4.58^{\mathrm{b}}$ \\
Total Protein (g/dL) & $7.89 \pm 0.61^{\mathrm{a}}$ & $7.43 \pm 0.52^{\mathrm{a}}$ & $4.36 \pm 0.24^{\mathrm{b}}$ & $4.75 \pm 0.43^{\mathrm{b}}$ \\
Total Bilirubin (mg/dL) & $1.25 \pm 0.05^{\mathrm{a}}$ & $1.23 \pm 0.04^{\mathrm{a}}$ & $1.95 \pm 0.08^{\mathrm{b}}$ & $1.97 \pm 0.07^{\mathrm{b}}$ \\
\hline
\end{tabular}

Values are expressed as mean $\pm \mathrm{SD} ; \mathrm{n}=10$. Values with different alphabetical superscript along a row are significantly different at $\mathrm{p}<0.05$. 
Table 2: Kidney function parameters in hepatitis B infected and non-infected patients obtained at NAFH, Ikeja Lagos.

\begin{tabular}{lcccc}
\hline Group & $\begin{array}{c}\text { Male } \\
\text { Non-hepatitis }\end{array}$ & $\begin{array}{c}\text { Female } \\
\text { Non-hepatitis }\end{array}$ & Male Hepatitis & Female Hepatitis \\
\hline Urea $(\mathrm{mmol} / \mathrm{L})$ & $2.67 \pm 0.08^{\mathrm{a}}$ & $2.83 \pm 0.06^{\mathrm{a}}$ & $5.64 \pm 0.15^{\mathrm{b}}$ & $5.70 \pm 0.13^{\mathrm{b}}$ \\
Creatinine $(\mathrm{mg} / \mathrm{dL})$ & $1.08 \pm 0.06^{\mathrm{a}}$ & $1.05 \pm 0.04^{\mathrm{a}}$ & $1.98 \pm 0.22^{\mathrm{b}}$ & $1.86 \pm 0.19^{\mathrm{b}}$ \\
Uric Acid $(\mathrm{mmol} / \mathrm{L})$ & $0.46 \pm 0.02^{\mathrm{a}}$ & $0.41 \pm 0.04^{\mathrm{a}}$ & $0.86 \pm 0.08^{\mathrm{b}}$ & $0.78 \pm 0.09^{\mathrm{b}}$ \\
$\mathrm{Na}^{+}(\mathrm{mmol} / \mathrm{L})$ & $142.76 \pm 9.41^{\mathrm{a}}$ & $139.87 \pm 8.22^{\mathrm{a}}$ & $102.64 \pm 5.30^{\mathrm{b}}$ & $108.51 \pm 4.72^{\mathrm{b}}$ \\
$\mathrm{K}^{+}(\mathrm{mmol} / \mathrm{L})$ & $4.87 \pm 0.36^{\mathrm{a}}$ & $4.69 \pm 0.41^{\mathrm{a}}$ & $2.88 \pm 0.24^{\mathrm{b}}$ & $2.92 \pm 0.21^{\mathrm{b}}$ \\
$\mathrm{Cl}^{-}(\mathrm{mmol} / \mathrm{L})$ & $101.60 \pm 7.33^{\mathrm{a}}$ & $102.64 \pm 6.93^{\mathrm{a}}$ & $88.96 \pm 5.66^{\mathrm{b}}$ & $86.54 \pm 6.32^{\mathrm{b}}$ \\
\hline
\end{tabular}

Values are expressed as mean $\pm \mathrm{SD} ; \mathrm{n}=10$. Values with different alphabetical superscript along a row are significantly different at $\mathrm{p}<0.05$.

\section{DISCUSSION}

Results obtained in this study showed significant elevation of liver marker enzymes (ALP, ALT and AST) in male and female hepatitis patients compared with their non-hepatitis counterparts. This is a clear indication of disruption of liver function induced by hepatitis B infection. Measurement of activities of marker enzymes in the serum plays a significant role in clinical diagnosis $(13,14)$. The elevation of these enzymes probably arose due to damage of the liver by hepatitis B virus thereby resulting in the release of the enzymes into the blood stream (15). The detailed mechanism by which enzymes are released from the cytosol and mitochondria of hepatocytes into the blood stream is not completely known. Clinical observations and experimental studies have shown that subtle membrane changes are sufficient to allow passage of enzymes to the intracellular space (16). A very large concentration gradient between the hepatocyte and the sinusoidal space usually exists for enzymes. Cell damage increases membrane permeability, causing cytosolic iso-enzymes to spill into the sinusoids and from there into the peripheral blood (17).

ALP is present in all human tissues but is particularly concentrated in the liver, bile duct, kidney and bone (18). ALT and AST are associated with liver parenchymal cells and are commonly measured clinically as biomarkers for liver health (19). The enzymes are of major importance in assessing and monitoring liver cytolytic hepatitis (20).

The significant reduction in total protein and elevation of serum total bilirubin in hepatitis B infected patients compared to the control is an indication of liver function disruption. Proteins are the building blocks of all cells and body tissues and they are synthesized in the liver. They help to balance the osmotic pressure of the blood and tissue. It may be concluded that hepatitis $\mathrm{B}$ infection has suppressed protein synthesis in the patients. Effective functioning of the liver leads to accurate ability of the liver to synthesize protein accurately. This mechanism is however impaired when liver function is disrupted (21). Serum total protein is also reduced in chronic infection, adrenal cortical hypofunction, hypersensitivity states, dehydration, respiratory distress, hemolysis and leukemia. Elevated serum bilirubin has been associated with hepatocellular damage, hepatic biliary tract obstruction and neonatal jaundice (22). Increased serum bilirubin level also indicates increased red blood cell haemolysis (23). Research has shown that bilirubin has a physiologic role as a cellular antioxidant (24).

The significant elevation of serum urea, creatinine and uric acid as well as reduction in serum electrolytes $\left(\mathrm{Na}^{+}, \mathrm{K}^{+}, \mathrm{Cl}^{-}\right)$in hepatitis $\mathrm{B}$ patients compared with non-hepatitis is an indication of kidney dysfunction in infected patients. Urea, creatinine and uric acid are markers of kidney function. They are waste product of metabolism found in the liver and carried in blood to the kidney for excretion. Functional kidneys remove these metabolites out of the blood into the urine efficiently but they remain in the blood when the kidneys are not functional. The observed reduction in serum $\mathrm{Na}^{+}, \mathrm{K}^{+}$ and $\mathrm{Cl}^{-}$in hepatitis subjects might be a result of electrolyte loss which arises due to dehydration or a result of kidney dysfunction caused by hepatitis B (25). It has been reported that the sera of patients with chronic HBV infection could induce apoptosis in human proximal renal tubular epithelial cells (26). Furthermore, the induction of apoptosis correlated with the level of circulating serum factor(s) in HBV carriers which could alter renal tubular cell function (27).

\section{CONCLUSION}

Results obtained in this study clearly indicate that hepatitis B infection caused significant derangement of metabolic functions in the liver and kidney of patients at NAFH Hospital, Ikeja Lagos. This was characterized by alteration of liver and kidney biomarkers measured in the serum compared with 
their non-hepatitis counterparts. This research confirms that other organ such as the kidney are negatively affected in hepatitis infection aside from the liver which is the principal target. There was no significant difference in values obtained for the two sexes both for hepatitis B infected and the noninfected. Data obtained in this study will further assist Clinicians in the use of liver and kidney function biomarkers for the diagnosis of hepatitis B infection in Western Nigeria.

\section{REFERENCES}

I. Orth S.R. and Ritz E. (1998). The Nephritic Syndrome. N. Engl. J. Med. 338: 1202-1211.

II. Macfarlane I., Bomford A. and Sherwood R.A. (2000). Liver Diseases and Laboratory Medicine. ACB Ventures Publications London. Pp. 67-72.

III. Custer B., Sullivan S.D., Hazlet T.K., Iloeje U., Veenstra D.L. and Kowdley K. (2004). Global epidemiology of hepatitis B virus. Journal of ClinicalGastroenterology 38. (Suppl. 3): S158-168.

IV. Dienstag J.L. (2008). Hepatitis B Virus Infection. New England Journal of Medicine 359 (14): 1486-1500.

V. Lok A.S. and McMahon B.J. (2007). Chronic hepatitis B. Hepatology. 45 (2): 507-539.

VI. Liaw Y.F., Brunetto M.R. and Hadziyannis S. (2010). The natural history of chronic HBV infection and geographical differences. Antiviral Therapy. 15: 25-33.

VII. Degertekin B. and Lok A.S. (2009). Indications for therapy in hepatitis B. Hepatology. 49:129-137.

VIII. Cameron J.S. and Greger R. (1998). Renal function and testing of function. Oxford Textbook of Clinical Nephrology. Davison A.M., Cameron J.S., Grunfeld J.P., Kerr D.N.S., Rits E.and Winearl G.C. Eds. Pp: 36-39.

IX. Alberti A. and Caporaso N. (2011). HBV therapy: Guidelines and open issues. Digestive and Liver Disease: 43 (Suppl 1): S57-63.

X. Lefevre M.L. (2014). Screening for Hepatitis B virus infection in non-pregnant adolescents and adults: U.S. Preventive Services Task Force recommendation statement. Annals of Internal Medicine 161 (1): 58-66.

XI. Gilbert R.D. and Wiggelinkhuizen J. (1994). The clinical course of hepatitis B virus-associated nephropathy. Pead. Nephrol. 8:11-14.

XII. Levy M. and Chen N. (1991). Worldwide perspective of hepatitis B-associated glomerulonephritis in the 80s. Kidney Int. Suppl 35: S24-S33.

XIII. Schmidt E. and Schmidt F.W. (1979). Enzyme diagnosis in diseases of the liver and biliary system. Adv. Clin. Enzymol. 1: 239-242.
XIV. Shahjahan M., Sabitha K.E., Jainu M. and ShyamalaDevi C.S. (2004). Effect of Solanum trilobatum against carbon tetrachloride-induced hepatic damage in albino rats. Indian J. Med. Res. 120: 194-198.

XV. Ghouri N., Preiss D. and Sattar N. (2010). Liver enzymes, nonalcoholic fatty liver disease and incident cardiovascular disease: A narrative review and clinical perspective of prospective data. Hepatology 52 (3): 1156-1161.

XVI. Giboney P.T. (2005). Mildly elevated liver transaminase levels in the asymptomatic patient, American Family Physician. 71 (6): 1105-1110.

XVII. Cotran R.S., Kumar V., Fausto N., Nelso F., Robbins S.L. and Abdul K. (2005). Robbins and Cotran pathologic basis of disease (7th ed.). St. Louis, MO Elsevier Saunders. p. 878.

XVIII. Akanji M.A., Olagoke O.A. and Oloyede O.B. (1993). Effect of chronic consumption of metabisulphite on the integrity of the kidney cellular system. Toxicol. 81: 173-179.

XIX. Berg J.M. Tymoczko, J.L and Stryer L. (2006). Biochemistry. W.H. Freeman. pp. 656-660.

XX. Nalpas B., Vassault A., Charpin S., Lacour B. and Berthelot P. (1986). Serum mitochondrial aspartate aminotransferase as a marker of chronic alcoholism diagnostic value and interpretation in a liver unit. Hepatology. 6 (4): 608-614.

XXI. Tredger J.M. and Sherwood K.A. (1997). The liver: New functional, prognostic and diagnostic tests. Annals of Clinical Biochemistry. 34: 121-141.

XXII. Renner E.L. (1995). Liver function test. Ballieres Clinical Gastroenterology. 9: 661-772.

XXIII. Kao T.W., Chou C.H., Wang C.C., Chou C.C., Hu J. and Chen W.L. (2012). Associations between serum total bilirubin levels and functional dependence in the elderly. Internal Medicine Journal.42 (11): 11991207.

XXIV. Sedlak T.W., Saleh M., Higginson D.S., Paul B.D. Juluri K.R. and Snyder S.H. (2009). Bilirubin and glutathione have complementary antioxidant and cytoprotective roles. Proceedings of the National Academy of Sciences. 106 (13): 5171-5176.

XXV. Shirley D.G., Walter S.J. and Noormohamed F.H. (2002). Natriuretic effect of caffeine: assessment of segmental sodium reabsorption in humans. Clinical Science. 103 (5): 461-466.

XXVI. Connor F.L., Rosenberg A.R., Kennedy S.E., Bohane T.D. (2003). HBV associated nephrotic syndrome: Resolution with oral lamivudine. Arch Dis Child. 88:446-449.

XXVII. Filler G., Feber J., Weiler G. and Saux N. (2003). Another case of HBV associated membranous glomerulonephritis resolving on lamivudine. Arch. Dis. Child.

$88: 460$ 